\title{
Nathalie Koble, «Les Prophéties de Merlin» en prose. Le roman arthurien en éclats
}

\section{G. Matteo Roccati}

\section{(2) OpenEdition}

1 Journals

\section{Édition électronique}

URL : https://journals.openedition.org/studifrancesi/2982

DOI : 10.4000/studifrancesi.2982

ISSN : 2427-5856

Éditeur

Rosenberg \& Sellier

\section{Édition imprimée}

Date de publication : 1 juillet 2013

Pagination : 428

ISSN : 0039-2944

\section{Référence électronique}

G. Matteo Roccati, « Nathalie Koble, «Les Prophéties de Merlin» en prose. Le roman arthurien en éclats », Studi Francesi [En ligne], 170 (LVII | II) | 2013, mis en ligne le 30 novembre 2015, consulté le 31 janvier 2023. URL : http://journals.openedition.org/studifrancesi/2982 ; DOI : https://doi.org/10.4000/ studifrancesi.2982

Ce document a été généré automatiquement le 31 janvier 2023.

\section{(c)}

Creative Commons - Attribution - Pas d'Utilisation Commerciale - Pas de Modification 4.0 International - CC BY-NC-ND 4.0

https://creativecommons.org/licenses/by-nc-nd/4.0/ 


\title{
Nathalie Koble, «Les Prophéties de Merlin» en prose. Le roman arthurien en éclats
}

\author{
G. Matteo Roccati
}

\section{RÉFÉRENCE}

NATHALIE KOBLE, «Les Prophéties de Merlin» en prose. Le roman arthurien en éclats, Paris, Honoré Champion éditeur, 2009 («Nouvelle bibliothèque du Moyen Age», 92), pp. 590.

1 Les Prophéties de Merlin sont un texte datable des années 1270, achevant en quelque sorte la production cyclique arthurienne. Elles se présentent comme la transcription à plusieurs voix - Merlin est «entombé» dans une montagne magique au cours du récit de prédictions énigmatiques relatives au conflit entre pape et empereur. Ces prédictions sont intégrées dans une trame narrative à entrelacement, nourrie de reprises et d'échos des textes antérieurs, l'action se situant dans sa plus grande partie au temps de la «fausse Guenièvre». La tradition manuscrite (dix-neuf témoins) est complexe: certaines copies réduisent le récit pour faire la part belle aux prophéties, d'autres développent la partie narrative. Le manuscrit Bodmer 116, le plus ancien et le plus complet, conservant «la meilleure copie de l'ensemble du texte» (p. 22), se présente comme un tout achevé, avec un prologue et un explicit: son étude permet d'appréhender une véritable œuvre d'auteur, d'une certaine manière dénaturée dans les manuscrits qui retiennent surtout la partie prophétique.

2 Le volume est organisé en trois parties. La première analyse la structure de l'œuvre puis examine, par le biais de la tradition manuscrite, sa réception, «majoritairement romanesque» (p. 26), et le «dispositif fictionnel particulièrement élaboré» (p. 27) qui l'organise. La seconde se penche sur les procédés d'écriture (répétitions, variations, récritures) où l'auteur s'efforce de rivaliser avec ses modèles, ainsi que sur son ouverture thématique à de nouveaux univers (l'Orient, la croisade en Terre sainte). 
Enfin la troisième partie traite des multiples «figures d'énonciation»(p. 30) qui apparaissent dans le roman et de la dimension féérique de celui-ci. En annexe est donnée l'analyse du texte d'après le manuscrit examiné (pp. 495-525); elle est suivie de la bibliographie (pp. 527-571) et des index des noms et des œuvres. 